\title{
Ontyczny i etyczny aspekt kosmoekologicznej koncepcji Świata
}

Honorata Korpikiewicz (Uniwersytet im. Adama Mickiewicza, Poznań)

\section{Wstęp: Kosmoekologia i hipoteza Gai-Uranosa}

Kosmoekologia, którą traktuję jako wiedzę o wpływie czynników kosmicznych na Ziemię i życie na niej - człowieka, innych zwierząt i roślin, zwróciła uwagę na związki istniejące pomiędzy ziemskim i kosmicznym środowiskiem (Korpikiewicz 2002). Człowiek najwcześniej zauważył zależność swego życia i całej ziemskiej biosfery od Słońca, przy czym najpierw doceniono wpływ jego promieniowania widzialnego i podczerwonego (cieplnego). Dopiero w l. 60. poznano promieniowanie korpuskularne (wiatr słoneczny) przybywający ze Słońca i uświadomiono sobie istnienie ziemskiej magnetosfery osłaniającej nas nie tylko przed tymże wiatrem (pasy van Allena), ale także wraz $\mathrm{z}$ heliosferą, przed wysokoenergetycznym promieniowaniem kosmicznym. Promieniowanie korpuskularne i niektóre zakresy promieniowania elektromagnetycznego zwiększają swe natężenie w zależności od aktywności słonecznej, co na Ziemi objawia się ogromną ilością zjawisk: burz magnetycznych, zakłóceń radiowych i zórz polarnych, zmianami pogody i klimatu, zmianami w wegetacji roślin i migracjami zwierząt, a także zwiększonym natężeniem wielu chorób, m.in. zakaźnych i układu krążenia.

Słońce i Księżyc mają zasadniczy wpływ na pogodę, co pociąga za sobą szereg zjawisk i wpływa na wszystkie organizmy. Oba te ciała przez swe działanie grawitacyjne wywołują zjawisko pływów, i to zarówno wód (co jest procesem najbardziej znanym) jak również pływów litosfery, mogących być przyczyną uwalniania się energii $\mathrm{w}$ trzęsieniach ziemi czy wybuchach wulkanów. Powodują też pływy atmosfery modyfikujące pogodę, a więc wpływające pośrednio na wegetację roślin i życie zwierząt. Rzadko bowiem zdajemy sobie sprawę, że to właśnie Słońce jest przyczyną zjawisk meteorologicznych na Ziemi (ruchy cząsteczek powietrza odbywają się pod wpływem energii kinetycznej udzielonej im przez Słońce), jak również, że zjawiska denudacji (erozji, wietrzenia) są wynikiem pośredniego lub bezpośredniego działania promieniowania Słońca (nagrzewanie skał, wiatry i deszcze), a także sił grawitacji.

Życie ziemskie powstało $\mathrm{w}$ wodzie, dlatego też $\mathrm{u}$ wszystkich organizmów morskich w ogromnym stopniu (w mniejszym - u lądowych) zauważa się organizację życia według pływów oceanów. Zwierzęta morskie rozmnażają się w ścisłej zależności od rytmu pływów. 
Od chwili powstania Ziemi opadał na nią pył kosmiczny jak również większe bryły ciał meteorowych. Obecnie w ciągu każdej doby spada 50-20 ton; w czasach początków Ziemi gęstość mgławicy protoplanetarnej była znacznie większa. Ciała meteorowe są przyczyną zmian stanu atmosfery (jej warstwy ozonowej) i zakłóceń w propagacji fal radiowych, a nawet katastrof na kosmiczną skalę. Do takich należały wielkie zderzenia, pozostawiające po sobie ślady w postaci ogromnych, wielokilometrowej średnicy kraterów. Liczne hipotezy łączą wypadki "wielkiego wymierania" zwierząt dawnych epok (m.in. 65 milionów lat temu) $\mathrm{z}$ masywnym zderzeniem Ziemi $\mathrm{z}$ kosmicznym ciałem. Pył pochodzący $\mathrm{z}$ rozpadu takiego ciała może zahamować dochodzące do Ziemi promieniowanie słoneczne, co odbija się w tragiczny sposób na biosferze. Również pył z obłoków pyłowych Galaktyki (mgławic ciemnych) może, podczas wędrówki Słońca wokół jądra Galaktyki, spowodować nadejście epoki lodowej.

Nie obojętne dla życia są także odleglejsze od Ziemi obiekty i pola siłowe. Promieniowanie widzialne wysyłane przez gwiazdy było podstawą nawigacji ludzi i zwierząt. Promieniowanie jonizujące wybuchających w pobliżu Słońca gwiazd supernowych może być niszczące dla ziemskiego życia szczególnie wtedy, gdy wydarzenie takie zbiegnie się $w$ czasie ze zniknięciem pola magnetycznego Ziemi i pozbawieniem biosfery ochronnej otoczki magnetosfery.

Pole elektryczne atmosfery okazało się wręcz niezbędne do życia. Zwierzęta pozbawione jonów ujemnych umierają nawet wtedy, gdy skład powietrza jest właściwy do oddychania (podobnie kosmonauci w statkach kosmicznych). Pole elektryczne atmosfery powstaje głównie za sprawą kosmicznej jonizacji górnych warstw atmosfery i utrzymuje określony stan ładunków elektrycznych powierzchni Ziemi, a także i tych, które płyną pod jej skorupą w postaci prądów wytwarzając pole magnetyczne naszej planety. Wszelkie zmiany pola magnetycznego, zarówno drastyczne (inwersja biegunów) jak i o słabszym natężeniu (burze magnetyczne, przebiegające w rytm aktywności Słońca) wpływają na organizmy roślin i zwierząt.

Najdłużej nie doceniano wpływu pola grawitacyjnego na rozwój organizmów, choć przecież w środowiskach, gdzie siła wyporu zmniejsza działanie siły grawitacji (np. w wodzie) organizmy charakteryzują się inną anatomią i fizjologią - np. innymi ośrodkami wytwarzania krwi. Badania eksperymentalne na Ziemi, jak również kosmiczne pokazują, że umiarkowanie zwiększona siła grawitacji może działać na organizmy pozytywnie, szczególnie na rozrost tkanki mięśniowej i kostnej, natomiast dłuższe przebywanie w stanie nieważkości jest niesprzyjające.

Wszechświat jest pełen zjawisk przebiegających rytmicznie; większość z nich zachodzi pod wpływem ruchów ciał po orbitach i ruchu wirowego wokół osi. Kosmiczne rytmy nie tylko modyfikują warunki życia na Ziemi, one są z nimi splecione od początku istnienia życia, a co więcej - są dla ich 
istnienia konieczne. Uwarunkowania te sięgają tak daleko, że bez pewnych grawitacyjnych rytmów - istnienia Księżyca i jego ruchu, nie byłyby spełnione podstawowe warunki dla życia na Ziemi, do jakich należy stabilność orbity. Życie nie mogłoby zaistnieć nawet wtedy, gdyby odpowiednia była odległość planety od Słońca, jej nachylenie do ekliptyki i obroty (Laskar, Joutel, Boudin 1982, 361).

Kosmiczne periody ruchu Ziemi wokół osi, dookoła Słońca, obiegu Księżyca wokół Ziemi oraz inne okresy obiegu i rezonanse - spowodowały w trakcie filogenezy powstanie u ziemskich organizmów szeregu rytmów, regulujących przebieg fizjologicznych reakcji organizmu w zależności od rytmów kosmicznych. Zajmuje się nimi chronobiologia, która jak gdyby wychodzi na przeciw kosmoekologii i wskazuje na odpowiedź adaptacyjną ziemskich organizmów na rytmy kosmiczne, jaką są właśnie rytmy biologiczne.

\section{Ziemia dla człowieka?}

Nie wiadomo, czy życie narodziło się we Wszechświecie w materii meteorytowej (w jądrach komet), czy w oceanach pra-Ziemi. Jednakowy kod genetyczny organizmów wskazuje na to, że ziemskie życie powstało z jednej jedynej pierwotnej komórki. Ale jednocześnie uświadamiamy sobie, jak mało prawdopodobny był "przypadek" utworzenia określonej sekwencji białek w budowie ziemskiego życia. Kontrowersyjne założenie o życiu przenoszącym się z planety na planetę, zwiększa obszar czasoprzestrzeni dla tego eksperymentu wszechczasów, jednocześnie zwiększając kosmiczne prawdopodobieństwo jego powstania. Choć wydaje się logiczne, że życie mogło powstać na wielu planetach innych słońc, to dotąd jego poszukiwanie nie przyniosło rezultatów. Może to wynikać z wielu przyczyn i nie przesądza, że życie we Wszechświecie istnieje tylko na Ziemi.

Z drugiej strony kłopoty interpretacyjne stwarzają implikacje idei antropicznej: nie tylko nasz zakątek Wszechświata, ale cały ogromny Kosmos, i to od początków jego powstania, od Wielkiego Wybuchu, posiadał ściśle określone parametry, bez których w dalekiej przyszłości życie białkowe nie mogłoby się narodzić (Barrow 1986). Czy więc życie jest atrybutem Wszechświata? I czy tylko uprzywilejowane zostało życie ludzkie, zgodnie z antropocentryczną interpretacją zasady oraz jej nazwą: „antropiczna”, czy raczej wszelkie życie, zrodzone $\mathrm{z}$ pierwszego ziemskiego organizmu, co postulują biocentrycznie nastawieni badacze, nazywając zasadę antropiczną - zasadą złożoności? ${ }^{1}$

Niektóre eksperymenty kwantowe wskazują na możliwość, że żyjemy we Wszechświecie nielokalnym (Barrow 1998), tj., że wszystkie elementy

\footnotetext{
${ }^{1}$ Autorka nazywa ją zasadą kosmoekologiczną.
} 
Świata są ze sobą powiązane i to, co uczynimy w jednym jego zakątku wpłynie na odległe w czasie i przestrzeni wydarzenia. Czyżbyśmy musieli uznać, że istnieje jakaś pierwotna korelacja, której istoty nie rozumiemy, a która jest zupełnie inna i głębsza od omawianych związków (wszechzwiązku) materii ziemskiej i materii kosmicznej?

Zależności kosmoekologiczne, pokazujące głębię powiązań pomiędzy poszczególnymi elementami Ziemi i Nieba, pozwalają widzieć w nich nierozerwalną całość, której części składowych nie sposób rozpatrywać oddzielnie bez istotnego naruszenia rozumienia ich wzajemnego funkcjonowania. Pojęcie superorganizmu Gai Lynn Margulis i Jamesa Lovelocka (Lovelock 2003) jest niepełne bez uwzględnienia jej związków z Niebem, w które Gaja jest wpleciona nie tylko w chwili obecnej, nawet nie w chwili powstawania, ale jeszcze wcześniej, od pierwszej chwili rodzącego się Wszechświata, gdy istniała jedynie w sferze potencjalnych wszechświatowych możliwości. Nie jest prawdą, że tylko człowiek, i to w ostatnich wiekach, zaczął kształtować swoje środowisko życia; to właśnie rodzące się życie od samego początku stwarzało i rozwijało coraz bardziej sprzyjające sobie środowisko.

Obecny stan wiedzy naukowej uzasadnia sformułowanie twierdzenia, że jesteśmy nie tylko zależni od pozostałych elementów ziemskiej biosfery, nie tylko wpisani w rytm zjawisk kosmicznych, które ukształtowały nas w taki, a nie inny sposób, ale nawet, że wszystkie te zależności były "zakodowane" w rodzącym się Wszechświecie od początku jego powstania. Pozwala to na objęcie wspólną nazwą środowiska spajającego nierozerwalnie Ziemię i Niebo, w którym wszystkie zjawiska są ze sobą powiązane. Hipotezę tę nazywam przez analogię do hipotezy Gai podwójnym imieniem greckich bóstw Ziemi i Nieba: hipotezą Gai-Uranosa (Korpikiewicz 2002; Korpikiewicz 2006).

Wszechświat, w którym narodziło się życie, musiał wprowadzić materię w określony sposób istnienia. Greccy filozofowie zauważyli, że w Świecie panuje symetria, proporcjonalność i harmonia. Widzieli jąw ruchu ciał niebieskich, które miały być jednostajne i odbywać się po orbitach kołowych, wyobrażali ją sobie w harmonijnych dźwiękach, jakie miały wydawać te ciała przy obrocie. Świat ziemski, odbicie świata platońskich idei, jako naśladownictwo, nie był tak doskonały, jednak i w nim odnaleźć można było harmonię w symetrycznej i proporcjonalnej budowie istot żywych, w budowlach wzniesionych ludzką ręką, w liczbach i konstrukcjach geometrycznych. Harmonią ze Światem miała być również świadoma egzystencja człowieka w środowisku, polegająca na koegzystencji z Naturą i życiu w zgodzie z samym sobą, w zdrowiu i poszanowaniu innych istot, jak to było w opisanym przez Owidiusza wieku złotym.

Postulowana doskonałość Świata, kryła w sobie wszak pewne niebezpieczeństwo: o ile Świat byłby w istocie doskonały (dokonały, czyli w rozumieniu Arystotelesa skończony, taki, który osiągnął swój cel), to nie 
mógłby się rozwijać. Zauważył to Empedokles, postulując przyjęcie, że doskonałość polega na niedoskonałości, czyli możliwości rozwoju. Na przykładzie harmonii: symetrii, proporcjonalności, a także odkrytych współcześnie innych struktur w pewnym sensie doskonałych, bo symetrycznych, samopowielających się, nieskończonych, jak pitagorejski pentagram, przejawiających się w istnieniu tworów Przyrody - np. fraktali, widać, że Natura nie realizuje do końca swoich możliwości. Ciała zwierząt i roślin nie są doskonale symetryczne, a płatki śniegu i linie brzegowe - nie są doskonale fraktalne. Także ciała niebieskie, które miały być zbudowane z doskonałej „piątej substancji” nie są dokładnie kuliste i poruszają się po krzywych stożkowych, a nie po okręgach. Nawet prawa Przyrody, które są w większości symetryczne, manifestują się nam poprzez łamanie symetrii. Czy w istocie Przyroda jest „niemal symetryczna”, jak to określił Richard Feynman (Feynman et al. 1969), a łamanie symetrii to jej sposób na rozwiązanie dylematu pomiędzy unifikacją a różnorodnością? Różnorodnością, która była konieczna dla rozwoju i mozolnego wspinania się na kolejne szczeble złożoności?

Konieczność istnienia w ewoluującym Świecie termodynamicznej nierównowagi została dostrzeżona w związku z rozwojem termodynamiki i problemem domniemanej śmierci cieplnej Wszechświata. Ale równowaga Wszechświata - to nie tylko równowaga termodynamiczna, to także tworzenie struktur trwałych. Z punktu widzenia sił jądrowych - są nimi atomy żelaza. Biorąc pod uwagę grawitację - to czarne dziury, maksymalna kumulacja materii i maksimum entropii. Dlaczego jednak siły Wszechświata nie dokonują swego dzieła, a raczej z rzadka dochodzą do struktur trwałych, jak wtedy, gdy tworzą atomy żelaza w końcowym etapie ewolucji gwiazdy czy czarną dziurę w przypadku gwiazdy masywnej? Dlaczego nie uczyniły tego krótko po Wielkim Wybuchu? Nie dokonało się to, co mogło się dokonać, ale przecież Wszechświat „doskonały”, równowagowy, nie mógłby się rozwijać. Rozwój trwałby jedynie tak krótko, jak mogłaby zaistnieć boltzmannowska fluktuacja.

Procesy równowagi i nierównowagi przeplatają się we Wszechświecie ze sobą, rywalizują zarówno w ewolucji gwiazdy, czarnej dziury, jak i ewolucji organizmów żywych (Korpikiewicz 1998). Obserwując stany nierównowagi możemy być jednak pewni, że układ się rozwija. Nierównowaga zwiastuje rozwój Wszechświata jako całości, jak również rozwój jego elementów składowych - gwiazd, planet, żywych organizmów.

Istnienie substancji Wszechświata w różnorodności jej form, co więcej - wręcz konieczność takiego właśnie urozmaiconego, różnorodnego Świata dość długo umykała uwadze filozofów. Starożytni Grecy widzieli Świat „uładzonym”, raczej jednolitym. Ich przekonania zaważyły na rozwoju europejskiej wiedzy po dzień dzisiejszy. Ale istniały także inne intuicje w tym względzie. W myśli prahinduskiej pojawił się pogląd o nieskończenie różnorodnej formie kosmicznej boga Kriszny, co zaowocowało współcześnie 
prahinduską zasadą kosmologiczną, sformułowaną przez Konrada Rudnickiego i Michała Hellera (Rudnicki 1995). Tym samym rozważania na temat cech dalekiego Kosmosu, konieczności istnienia jego różnorodności, wyprzedziły zauważenie różnorodności biologicznej - bioróżnorodności. Zwracał na nią wprawdzie uwagę już Karol Darwin, ale doceniono jej wartość dopiero w ostatnim półwieczu.

Konieczność istnienia różnorodności (urozmaicenia), potrzebnej zarówno dla istnienia i ewolucji elementów Świata, jak również dla opisu jego zjawisk, podnosił w swej relacyjnej teorii czasu i przestrzeni Leibniz (Leibniz 1991). Jego przekonanie o nieistnieniu absolutnej przestrzeni i czasu oraz własnościach elementów Świata, które także nie są absolutne, dane na stałe, ale zależą od ich relacji z innymi elementami, zostały potwierdzone przez teorię względności oraz chromodynamikę kwantową. U podstaw teorii kwarków - podstawowych cząstek Wszechświata - leży fundamentalne prawo Natury, że własności ciał nie mają znaczenia absolutnego, tylko są wypadkowa związków zachodzących pomiędzy nimi.

We Wszechświecie zdarza się więc obserwować symetrię, równowagę, proporcjonalność. Jednak zawsze pozostaje pewien niewykonany do końca krok, wąski margines dla działań ewolucyjnych, który okazał się warunkiem koniecznym dla rozwoju, pomnażania różnorodności i złożoności, a w konsekwencji także dla ewolucji biologicznej. Wszechświat doskonale symetryczny pod względem ciał, wytworów nieożywionych i praw, pozostający $\mathrm{w}$ trwałej równowadze, pod każdym względem dokończony, doskonały, jak doskonała jest rzecz, która osiągnęła granice swego rozwoju, nie mógłby się rozwijać, nie mogłaby w nim przebiegać ewolucja materii ani na poziomie biologicznym ani na poziomie materii nieożywionej. Musi więc pozostawać nierównowagowy, nie do końca harmonijny, różnorodny i złożony, ale i rytmiczny, żeby stworzyć warunki dla kosmicznej ewolucji. I to zarówno ewolucji gwiazdy, mgławicy, jak i człowieka, psa czy ryby trzonopłetwej.

\section{Etyka holistyczna i patocentryczna}

Przyjęcie hipotezy Gai-Uranosa ma oprócz aspektu ontycznego także aspekt etyczny. Etyki naturalistyczne (aksjologie naturalistyczne) normy etyczne wywodzą z Natury: dobre jest to, co jest zgodne z przyrodniczą naturą człowieka. Bywa, że ich zwolennicy koncentrują się na wywodzeniu zasad etycznych z niezwykle zawężonego spojrzenia na naturę ludzką, mającą się jakoby sprowadzać głównie do dawania i zachowania życia, jako najważniejszej potrzeby biologicznej. Stąd koncentracja na problemach związanych z rozmnażaniem się człowieka, podczas gdy mniej ważne stają się inne podstawowe potrzeby biologiczne (np. bezpieczeństwa, zachowania zdrowia, zaspokojenia głodu, ogrzania ciała czy zaspokojenia seksualnego), albo potrzeby wyższe - np. rozwoju twórczego, które często stoją w opozycji 
do potrzeby rozmnażania. Takie podejście prowadzi prostą drogą do królującej od wieków etyki antropocentrycznej.

Nie zauważa się przy tym, że natura ludzka rozwinęła się w trakcie długiej filogenezy i dziedziczy swe cechy po zwierzęcych przodkach. To od nich wywodzi się podstawowe dążenie - do zachowania życia - instynkt samozachowawczy, choć też nie zawsze jest ono wartością naczelną. Zarówno wśród ludzi jak i wśród zwierząt obserwuje się poświęcanie swojego życia czy samookalecznia.

Wizja Świata według kosmoekologii prowadzi nas prostą drogą do etyki holistycznej (o os $_{\text {- }}$ cały, /gr./), najszerzej pojętej etyki środowiskowej, obejmującej nie tylko ziemskie ale także kosmiczne środowisko, wraz ze wszystkimi jego elementami zarówno żywymi jak i nieożywionymi. Podstawową zasadą jest poszanowanie Natury w każdym jej przejawie.

Przyjęło się uważać, że Natura i zachodzące w niej procesy są aksjologicznie obojętne, bo tylko człowiek jest podmiotem wartościującym i tylko w stosunku do niego (jego dobrostanu, zdrowia czy życia) można oceniać zachodzące wokół niego zdarzenia. Dawny człowiek tworzył swe etyczne postawy w sposób intuicyjny i twierdzę, że wzorował się przy tym na obserwacji Natury. Jednakże nie na „rozrzutnej” Przyrodzie $\mathrm{z}$ „zakrwawionymi zębami i pazurami”, jak to dobitnie i ironicznie określił pisarz John Wyndham, ale na bardziej podstawowej obserwacji: kierunku przebiegu wszystkich procesów fizycznych, któremu próbował się przeciwstawiać. Obserwacji takiej musiały dokonać także zwierzęta wyższe, które wykształciły w swych społecznościach zasady hamowania agresji i jej rytualizacji w stosunku do członków swojego gatunku, a więc, jak je nazwał Konrad Lorenz, „zbieżne z moralnością”.

Jak uzasadniam, istnieją w Naturze czynniki immanentne, które sprawiły, że pewne czyny i wydarzenia uzyskiwały w oczach człowieka aprobatę jako "dobre", a inne traktowane były jako "złe" (Korpikiewicz 1998). Nieoczekiwanie wiąże się to $\mathrm{z}$ pytaniem etyki holistycznej, nazywanym umownie "problemem wydmy": czy mamy prawo naruszać stan materii nieożywionej, która nie czuje i nie żyje?

Jednym z podstawowych praw fizyki, rządzących zarówno na Ziemi jak i w każdym zakątku Wszechświata, jest prawo wzrostu entropii, którą można w pewnym uproszczeniu przedstawić następująco: $w$ procesach przebiegajacych we Wszechświecie entropia stale wzrasta. Wielkość fizyczna, zwana entropią, która ma ścisły sens matematyczny, przybliżana jest często pojęciami "rozpadu", "rozproszenia", "degeneracji, "zmniejszonego porządku" itp.

Każda żywa istota $\mathrm{w}$ trakcie swego rozwoju styka się bez przerwy ze zjawiskiem rozsypki, rozpadu. Gniją szczątki martwych organizmów, skały ulegają denudacji, rozpadają się budowle wzniesione ręką człowieka. 
Obserwowane na każdym kroku, w każdej chwili, procesy wzrostu entropii są tak nieodłączne naszemu życiu, że ich sobie w ogóle nie uświadamiamy, jak przez wieki człowiek nie uświadamiał sobie istnienia powietrza czy wpływu grawitacji na organizm. Jednak to właśnie zjawisko, zakodowane w naszym umyśle od początku jego rozwoju daje odpowiedź na odwieczne pytanie o niezwykłą siłę zła w stosunku do sił dobra: dlaczego tak łatwo coś zniszczyć albo życie unicestwić, podczas gdy proces odwrotny jest bądź niezmiernie trudny bądź wręcz niemożliwy do przeprowadzenia.

Obserwując przez miliony lat nieodwołalne zniszczenia związane z podmywaniem brzegów rzek, osypywaniem się piargów na dno doliny, zawalaniem się ścian skalnych, pożarami stepów czy domostw, człowiek zaczął te właśnie zjawiska traktować jako "złe". Odwrotnie - prace związane z trudem budowy, tworzenia, odtwarzania zniszczonych struktur, były "dobre" - ale o wiele trudniejsze do wykonania. Człowiek prędko zrozumiał, że śmierć współplemieńca stanowić może o zagrożeniu grupy, a zniszczenie domostw przez powódź czy lawinę prowadzi do pogorszenia warunków bytowania, a nawet może wieść do utraty życia. Z uświadomienia sobie tego faktu wyrósł pierwszy moralny obowiązek prowadzący do próby przywrócenia równowagi, zaburzonej przez kataklizmy czy innych ludzi lub zwierzęta. Stąd, jak sądzę, współczesne intuicje moralne wyrażające podstawową zasadę etyki holistycznej: nie naruszania stanu naturalnego. Człowiek próbował wrócić życiu zabitą istotę; to jednak było niemożliwe. Sposobem na przywrócenie równowagi były narodziny kolejnych dzieci; stąd pochodzenie magii i kultu płodności, występujących we wszystkich chyba kulturach; w dalekiej przyszłości miały one przekształcić się $\mathrm{w}$ poszanowanie ludzkiego życia, a w wysublimowanej postaci - w szacunek dla wszelkiego życia.

Chociaż przywracanie równowagi w zakresie usuwania materialnych zniszczeń po niszczycielskiej działalności ludzi lub żywiołów było możliwe (odbudowa domostw), to było ono o wiele trudniejsze od dokonywania zniszczeń. Unoszenie przedmiotów ponad powierzchnię Ziemi (przeciwdziałanie sile grawitacji) jest jednocześnie przeciwdziałaniem siłom entropii, dążącym do osiągnięcia maksymalnej wartości i sprowadzenia każdego nie podtrzymywanego przedmiotu możliwie jak najbliżej środka Ziemi. Przeciwdziałanie spontanicznej dążności do wzrostu entropii było znacznie trudniejsze, jednak miało dla człowieka ogromną wartość, jako budujące, tworzące, konsolidujące. Stawało się dobre, w przeciwieństwie do degradującego i sprzyjającego rozpadowi zła.

Dla istot (ludzkich i zwierzęcych) żyjących w społeczeństwach, zachowanie pierwotnego porządku i nienaruszanie stanu naturalnego, wiązało się za współodczuwaniem. W ludzkim rozumieniu dobra i zła osobnik "dobry" dla społeczeństwa to taki, który współodczuwa z innymi jednostkami ludzkimi i przyczynia się do ich przetrwania. Tak samo jest u zwierząt - bez współodczuwania wspólnych potrzeb grupa, stado, społeczność - nie byłaby 
w stanie przetrwać. Konieczność współpracy a nie konkurencji i walki podkreślał wybitnie m.in. Piotr Kropotkim, pisząc o „pomocy wzajemnej”, a współcześnie Lynn Margulis. Każda komórka w organizmie żywym współpracuje $\mathrm{z}$ innymi komórkami w tkance, ponieważ $\mathrm{w}$ jakiś sposób odczuwa ich potrzeby. Gdyby nie współodczuwała i/lub nie chciała współpracować, organizm uległby zniszczeniu (tak jest np. w przypadku rozwoju komórek rakowych). Analogicznie - można by więc uznać, że komórki współpracujące (empatyczne) są dobre. Zaczątków współczucia należałoby więc poszukiwać nie u człowieka i nawet nie u zwierząt wyższych, ale wśród organizujących się komórek. "Miłosierdzie, współczucie i życzliwość nie są przymiotami uczuć wyłącznie człowieka. Rozwinęły się z powszechnych tendencji w naturze, zgodnie z procesem ewolucji" (Chopra 1994, 129).

Więc to nie redukcjonizm teorii „samolubnego genu” prowadzący do przekonania, że rozwój następuje przez ochronę i rozprzestrzenianie własnych genów, ale szerzej pojęta współpraca, altruizm, współodczuwanie/współczucie, jest istotnym motorem rozwoju. Można dojść do wniosku, że właśnie współodczuwanie powinno stanowić podstawę wartościowania, przynajmniej ludzkich uczynków, choć większość zwierząt wyższych także jest zdolna do empatii (Korpikiewicz 2011). Jednakże paradoksalne, że zarówno etyki jak i religie ze swoimi kanonami przykazań, rzadko zajmują się współodczuwaniem, współczuciem, cierpieniem. Wyjątki to m.in.: dżinizm i buddyzm z zasadą ahinsy - nie czynienia krzywdy żadnej żywej istocie, nie stosowania przemocy.

Etyka patocentryczna ( $\pi \alpha \vartheta o \varsigma$ - namiętność, pasja, cierpienie, ból /gr./) - której naczelną zasada jest nie zadawanie cierpienia - wypływa z intuicji Wschodu, ale ma też swe źródła zarówno w ludzkiej wrażliwości i empatii jak i wiedzy naukowej - fizjologii, psychologii, etologii, pouczających nas, że procesy życiowe i zachowania zwierząt nie różnią się w sposób istotny od naszych. Zasada niekrzywdzenia nie jest bezpośrednio związana z zachowaniem życia ani gatunku, przekracza więc zarówno zachowania naturalne (instynkt samozachowawczy) jak i normy etyki biocentrycznej (ochrony życia istot nieludzkich), a tym bardziej zasadę ochrony gatunkowej, która ingeruje w zachowanie i rozwój gatunków nie licząc się z cierpieniem i utratą życia, np. przez odławianie zwierząt i trzymanie ich w nienaturalnych warunkach w ogrodach zoologicznych. Takiej wrażliwości patocentrycznej zabrakło dyrektorowi kopenhaskiego zoo, który wydał decyzję o zamordowaniu 9 II 2014 młodej, zdrowej żyrafy o imieniu Marius, bo pochodziła ze związku kazirodczego, a więc miała „niewłaściwy genotyp”. Pomijam okrucieństwo wobec dzieci, które oglądały to barbarzyńskie widowisko, i metodologiczny fałsz oraz hipokryzję, polegające na wmawianiu opinii publicznej, że „demonstrowane są prawa przyrody”, a więc - domyślnie - jeśli Przyroda „ma zakrwawione zęby i pazury”, to i człowiek może zachowywać się tak samo. Jednakże trudno równać konieczność życiową 
upolowania kopytnych na sawannie przez drapieżnika z zamordowaniem przez człowieka młodego, zdrowego zwierzęcia, będącego pod jego opieką.

Ten uczynek pokazał, że okrutna jest nie Przyroda, ale świat ludzi, nie kierujący się współodczuwaniem, tylko normami unijnymi, i mógł u osób wrażliwych pozostawić traumę na całe życie, a u osobników psychopatycznych być zachętą do zabijania innych stworzeń. Najwyższy czas wrócić do zapomnianej dyskusji o sensowności utrzymywania ogrodów zoologicznych, instytucji nieetycznych, przetrzymujących zwierzęta w warunkach więziennych i uzurpujących sobie prawo do kierowania ich ewolucją 2 .

Niestety, każda hodowla niesie podobne zagrożenia, choć na ogół rzadziej nagłaśniane. Wybór zwierząt domowych do hodowli wiąże się w najlepszym przypadku ze sterylizacją i kastracją, w najgorszym - z zabiciem zwierzęcia, nie odpowiadającego kanonom np. kynologicznym. Zwrócę uwage na niezwykłą ambiwalencję ludzkich dążeń: z jednej strony człowiek docenia bioróżnorodność. Z drugiej - kastruje wszystkie nierasowe (jakże różnorodne!) psy i koty. (I nie toleruje chwastów na trawniku). Przyczyna jest jasna: ludzie chcą kupować zwierzęta rasowe...

\section{W stronę wspólnego Świata}

Posiadanie przez Homo sapiens świadomości i zdolności do myślenia jest zgodne z zasadą ewolucyjnej ciągłości - odziedziczyliśmy nasz umysł po zwierzęcych przodkach, rozwijając i sublimując go w ciągu milionów lat. Wraz z nim wysublimowaliśmy swoje zasady etyczne. Nasze ciała i układ nerwowy rozwijały się w powiązaniu z innymi gatunkami, a na nas wszystkich w podobnym stopniu wpływały i nadal wpływają, czynniki kosmiczne. Zarówno hipoteza Gai jak i rozszerzona Hipoteza Gai-Uranosa pokazuje sieć związków ziemskich i kosmicznych, w którą są wplecione wszystkie ziemskie organizmy, bez wyjątku. Nie ma pomiędzy nimi/nami żadnych różnic jakościowych - są natomiast różnice ilościowe w poziomie rozwoju zarówno budowy anatomicznej ciał jak rozwoju umysłu. Jednak dla wszystkich najcenniejsze jest ich życie, wszystkie odruchowo lub świadomie unikają cierpienia i śmierci.

Człowiek „antropocentryczny”, podnoszący wartość swojego życia, swojego cierpienia i dobrostanu, nie zauważający cierpienia innych istot, jest już przeżytkiem jakkolwiek nie miło by to dla nas nie zabrzmiało. Nie ma żadnego uzasadnienia (ewolucyjnego, naukowego czy religijnego)

2 Nie wszystkie ogrody zoologiczne zabijają zwierzęta w imię „właściwego” (?) rozwoju gatunku. Są też głównie nastawione na komunikację - bliski kontakt z człowiekiem, który może je karmić i się z nimi bawić. Znam jednak tylko dwa takie miejsca na świecie: Lujan ZOO koło Buenos Aires (Argentyna) oraz klasztor buddyjski - Świątynia Tygrysów Luangta Bua Yansampanno, (Tajlandia) gdzie mnisi opiekują się m.in. dzikimi tygrysami. 
na lekceważenie, pomijanie czy pomniejszanie cierpienia innych istot, przez niewiedzę, hipokryzję czy pseudonaukowe albo religijne teorie (behawioryzm, kartezjanizm i in.), uzurpujące sobie prawo do czynienia im krzywdy. 0 wrażliwości, emocjach, uczuciach wyższych zwierząt napisano wiele prac i nie ma naukowych podstaw podważać tej wiedzy. Jednak tym wrażliwym, czującym, tak do nas podobnym w swym odczuwaniu, naszym „braciom mniejszym" człowiek wciąż urządza piekło na Ziemi, jakiego powinna się wstydzić istota rozumna.

Noblista Isaac Bashevis Singer, więzień hitlerowskiego obozu koncentracyjnego w Treblince, napisał: "Dla zwierząt wszyscy ludzie to naziści a ich życie to wieczna Treblinka". Doskonale zdawał sobie sprawę z tego, jak się czuje istota zaszczuta, poniżana, zadręczona, katowana, pozbawiona jakiejkolwiek nadziei, i to niezależnie od jej przynależności gatunkowej.

Wspólny świat istnieje, jednak wciąż nie zdajemy sobie z tego sprawy. Nie przeżyjemy bez tlenu wytwarzanego przez rośliny, bez bakterii zasiedlających nasze jelita, bez owadów zapylających rośliny i innych gatunków, powiązanych z nami niezbadaną jeszcze do końca siecią powiązań. Jednak nie dla naszych egoistycznych pragnień przeżycia powinniśmy te istoty szanować. Są takimi samymi jak my mieszkańcami planety Ziemia i tak samo jak my mają prawo do życia w dobrostanie i bez cierpienia. Taka postawa to zrozumienie naszego miejsca w świecie i odrobina pokory wobec wielkiego Wszechświata, który nas wszystkich zrodził.

\section{Bibliografia}

Barrow, J.D. \& Tipler F.J. 1986. The Anthropic Cosmological Principle. Oxford: Clarendon Press.

Barrow, J.D. 1998. Wszechświat a sztuka. Tłum. J. Skolimowski. Warszawa: Amber.

Chopra, D. 1994. Twórzmy zdrowie. Przez profilaktykę do doskonałości. Tłum. E.M. Skweres. Warszawa: PWN.

Feynman, R., Leighton, R., \& Sands, M. 1969. Feynmana wykłady z fizyki. Tom. 1. cz.2. Tłum. A. Jurewicz, M. Grynberg, M. Kozłowski, \& T. Butler. Warszawa: Państwowe Wydawnictwo Naukowe.

Korpikiewicz, H. 1998. Koncepcja wzrostu entropii a rozwój Świata. Poznań: Wydawnictwo Naukowe UAM.

Korpikiewicz, H. 2002. Kosmoekologia z elementami etyki holistycznej. Hipoteza Gai-Uranosa. Poznań: Prodruk.

Korpikiewicz, H. 2006. Kosmoekologia. Obraz zjawisk. Poznań: Wydawnictwo Naukowe UAM.

Korpikiewicz, H. 2011. Biokomunikacja. Jak zwierzęta porozumiewają sie ze światem. Poznań: Wydawnictwo Naukowe UAM. 
Laskar, J., Joutel, F. \& Boudin, F. 1982. „Stabilization of the Earth`s obliquity by the Moon", Nature (361): 615 - 617.

Leibniz, G.W. 1991. Monadologia. Tłum. H. Elzenberg. Toruń: Uniwersytet Mikołaja Kopernika.

Lovelock, J. 2003. Gaja. Nowe spojrzenie na życie na Ziemi. Warszawa: Prószyński i S-ka.

Rudnicki, K. 1995. The Cosmological Principles. Kraków: Jagiellonian University. 
Honorata Korpikiewicz (Uniwersytet im. Adama Mickiewicza, Poznań)

\title{
Ontyczny i etyczny aspekt kosmoekologicznej koncepcji Świata
}

\begin{abstract}
Abstrakt: W artykule krótko podsumowałam swoje dotychczasowe rozważania nt. rozwijanej przeze mnie dziedziny kosmoekologii. Wskazałam więc na najważniejsze wpływy kosmicznego środowiska na ziemskie życie, co uzasadnia hipotezę Gai-Uranosa. Rozważyłam także pokrótce, jakie cechy musiały charakteryzować kosmiczne środowisko, żeby w naszym zakątku Wszechświata powstało i ewoluowało życie. Problem fizycznych parametrów środowiska kosmicznego, koniecznych dla zaistnienia życia, był zauważany od wieków; rozważania te znalazły swe apogeum w zasadzie antropicznej. Tutaj wymieniam najogólniejsze cechy, jakie musiało posiadać środowisko kosmiczne: harmonię, różnorodność, nierównowagę i rytmikę zjawisk. Takie spojrzenie na rozwój życia na Ziemi wpływa na rozumienie miejsca człowieka w świecie, pośród innych wytworów Natury, poprzez postawę etyki holistycznej i patocentrycznej.
\end{abstract}

Słowa kluczowe: Kosmoekologia, hipoteza Gai-Uranosa, różnorodność, etyka holistyczna i patocentryczna 
Honorata Korpikiewicz (Adam Mickiewicz University, Poznań)

\title{
Ontic and ethical aspects of the cosmoecological concept of the world
}

\begin{abstract}
In this article I provide a summary of insights on the discipline of cosmoecology. I point out the most important cosmic influences on life on Earth, which justifies the hypothesis of Gaia-Uranos. I consider what kind of features must have characterized the cosmic environment in order for life to evolve in this part of the Universe. The problem of physical parameters of the cosmic environment, necessary for the existence of life, has been recognized for centuries; these considerations find their apogeum in the anthropic principle. Here, I discuss the general features of the cosmic universe: harmony, diversity, non-balance, and the rhythms of phenomena. This perspective on the development of the life on Earth influences the understanding of the human place in the universe, among others creations of nature, through the lens of holistic and pathocentric ethics.
\end{abstract}

Keywords: Cosmoecology, Gaia-Uranos hypothesis, diversity, holistic and patocentric ethics

Ethics in Progress (ISSN 2084-9257). Vol. 5 (2014). No. 1. pp. 137-150.

doi:10.14746/eip.2014.1.12 